Edyta Mioduchowska-Jaroszewicz

Katedra Analizy i Strategii Przedsiębiorstw

Wydział Nauk Ekonomicznych i Zarządzania

Uniwersytet Szczeciński

\title{
Summary
}

\section{Usefulness of sectoral means in financial analyses of enterprises}

\section{Aim}

The aim of the paper is to assess the usefulness of sectoral means in financial analyses of enterprises.

\section{Research methods}

The article uses an inductive-deductive approach to assess the suitability of sectoral means used in analyses of financial standings of enterprises. The method of analysis and logical construction was used for literature review. The methods of descriptive statistics such as, arithmetic means, standard deviation and coefficient of variation were used in order to analyze the data and draw conclusions based on the results.

\section{Contribution}

The assessment of the usefulness of sectoral means in the context of their variability seems to be a crucial aspect for the analysis of a company's financial situation. When assessing the financial standing of an enterprise, it is necessary to use a comparative analysis method, based on, inter alia, a comparison in space. This type of comparison requires the use of sectoral means, whose assessment is extremely important to drawing reliable and correct conclusions of the financial situation of a company.

Key words: financial analysis, coefficient of variation, sectoral ratios, financial ratios

\section{Introduction:}

Analytical studies should aim at making 'similar-to-similar' comparisons. Thus, it is necessary to compare the indicators characterizing the activity of a studied enterprise with:

- its current competitors,

- its potential competitors,

- and other enterprises that operate in those market segments to which the company enters or intends to enter.

The significance of this dimension of comparisons lies primarily in the fact that it allows one to assess the competitive position of a company, which requires reasoning in terms of opportunities and threats, especially strengths and weaknesses. Enterprises that serve as a 'reference point' enable one to characterize the closer (sectoral) environment in which an enterprise operates. It is a sine qua non condition for formulating judgments as to the position of the company in the sector, especially when taking into account its efficiency, which determines the company's ability to continue its operations. The comparison in space in its essence is similar to external (competitive) benchmarking, which aims to evaluate a company's competitive advantage against the background of its competitors. It stands in contrast to functional benchmarking, which aims to find a pattern in other companies performing similar functions.

The cognitive value of the results obtained based on the comparisons is dependent on the degree of comparability of indicators, which may be disturbed by certain methodological differences. This applies mainly to comparisons with another enterprise (or other enterprises), especially when 'ready-made' indicators are used without sufficient knowledge as to their usage and calculations. Thus, it must be remembered that there are no standards, neither national nor international, in the area of constructing financial ratios. 
In the case of sectoral comparisons, one should bear in mind the fact that the distribution of observation values (i.e., indicators) is rarely normal. Therefore, applying arithmetic or weighted means, which are the basic tools used to calculate sectoral or industry ratios, may lead to false conclusions. It is therefore necessary to use descriptive statistics tools that enable a more precise placement of the examined enterprise in the sectoral environment (Dudycz T., Hamrol M., Skoczylas W., Germany A.2005).

Finally, conclusions were drawn regarding the comparability and significance of other statistical measures than the averages used in the analysis of sectoral means.

\section{Literature Review}

Bernstein and Wild (1999) state that in traditional financial analysis, ratios represent the final product of the research, as the diagnosis of a specific area of the company is generated based on them. The difference from predictive analysis can be seen here, in that the ratios constitute the raw material that will be processed using statistical techniques and mathematical modeling. These techniques have played a part in generating interest in ratios, leading to an explosion in their use in multiple economic studies. However, it is necessary for the scientific world to know not only about the instruments to be applied, but also accounting science in order to take advantage of their full potential.

In his research, M. Hamrol (2013) points out that the cognitive value of results obtained as a result of the comparisons made is dependent on the degree of comparability of indicators, which may be disturbed by certain methodological differences. This applies mainly to comparisons with another company or other companies, especially when one uses 'ready-made' indicators, without sufficient knowledge about how to count them. It must be remembered that there are no standards, neither national nor international, in the area of constructing financial ratios.

P. Figura (2012), in his monograph aiming to estimate sectoral ranges of recommended values of selected financial ratios for listed companies, showed that recommended ranges of model values of financial ratios are not an effective criterion for assessing the financial condition of listed enterprises. The recommended values and ranges of reference values are significantly different in particular sectors of the Polish economy. Listed companies, which form a group of sectoral leaders, create values of financial ratios that deviate from the literature reference values. The conducted research confirmed that in the vast majority of cases there were statistically significant differences between the sectoral distributions of values of particular indicators, which were designated for leading enterprises.

On a sector level, given that in financial ratios it is common for extreme atypical values to appear as the result of dividing by very small terms (e.g., Ezzamel, Mar-Molinero, 1990; Frecka, Hopwood, 1983; Kane, Richardson, Meade, 1998), it is not recommendable to use the mathematical mean of the sector ratios as a parameter to represent the set of companies in the industry. This is due to the fact that the extreme values can distort the interpretable results of an aggregate function that is sensitive to them. Oliveras and Moya (2005) warn that if any of the ratios for a sector is very different from the sector mean, the cause must be investigated. In this sense, the present article advises that a single outlier can cause the difference.

Due to problems with asymmetry in the ratio distribution, largely accentuated by the outliers, it is not unusual that the ratio analysis literature has shown a number of works that propose an initial transformation in the data obtained. This includes Box-Cox transformations (Ezzamel, Mar-Molinero, 1990; Mcleay, Omar, 2000; Watson, 1990), logarithmic transformations (Cowen, Hoffer, 1982; Deakin, 1976; Sudarsanam, Taffler, 1995), transformations by ranges (Kane et al., 1998), by square roots (Deakin, 1976; Frecka, Hopwood, 1983; Martikainen, Perttunen, Yli-Olli, Gunasekaran, 1995), by generalized risk box (Bahiraie, Azhar, Ibrahim, 2010), and other processing methods, such as weight of evidence (Nikolic, Zarkic-Joksimovic, Stojanovski, Joksimovic, 2013), outlier trimming (Ezzamel, Mar-Molinero, 1990; Frecka, 
Hopwood, 1983; Lev, Sunder, 1979; Martikainen et al., 1995; So, 1987; Watson, 1990), and outlier winsorization (Lev, Sunder, 1979).

Last work of Rondós-Casas et al. (2018) has shown the usefulness of an alternative methodology for calculating sector ratios. This provides more reliable information on the capacity of a sector to globally return its debt over the short term. It therefore determines with greater precision both is payment capacity and its timeliness. The ideas are applied in a specific sector in order to find the deviations between the results that have been obtained using the classic ratios and those proposed in this work. The results have shown sufficiently disperse values that corroborate the need to implement these new indicators. This work has important repercussions on both an academic and social level. On the one hand, the work opens new channels for determining the ideal ratio in a sector. On the other hand, the work warns that current praxis must be refined in the area of sector analysis.

Thus, the literature review indicates that there is a problem in the use of average sectoral financial ratios in assessing the financial situation of enterprises.

\section{Hypotheses and research questions}

H1: The profitability ratios are more variable than the liquidity ratios.

$\mathrm{H} 2$ : The debt ratio is characterized by the highest stability of results. Which indicators are subject to the smallest fluctuations?

H3: The usefulness/variability of sectoral ratios does not depend on the type of information used to calculate their value.

H4: From a sectoral perspective, the variability of financial results makes it impossible to use them properly in the assessment of the financial standing of enterprises.

H5: Financial results of particular sectors differ due to the lack of stability in shaping financial results. Which sectors are characterized by greater volatility of financial results?

H6: Ratios based on cash accounting data are more stable than those based on accrual data.

\section{Research Methods}

The coefficient of variation was used to analyze the variability of financial results, which is the relation of a standard deviation and an arithmetic mean. The coefficient of variation is a classical measure of variation in the distribution of features or values. In contrast to the standard deviation, which determines the absolute differentiation of features, the coefficient of variation is a relative measure, which means that it is dependent on the size of the arithmetic mean. It is defined by the formula:

$$
V=\frac{S}{\underline{X}} \quad \underline{X} \neq 0
$$

Where:

$S$ - is a standard deviation,

$\underline{X}$ - is an arithmetic mean.

The results of the coefficient of variation are interpreted as follows:

- $V<0,2-$ low variability,

- $0,2<V<0,4$ - average variability,

- $0,4<V<1-$ high variability,

- $1<V<1,5$ - very high variability,

- $V>1,5-$ extremely high variability.

To meet the aim of this study the Author used 16 indicators, whose formulas are presented in Table 1. The sectoral ratios used in the study were selected due to the four criteria of assessing the financial situation of a company: profitability, financial liquidity, debt and risk. The first group of indicators includes profitability ratios: operating profitability, return on equity, return on net sales, return on sales basics, and economic return on sales. The second group of indicators was used to assess financial liquidity based on a static approach (current financial 
liquidity, quick liquidity, payment period of short-term receivables,payment period of liabilities, the speed of inventory turnover) and a dynamic approach (cash-flow and cash assets), whilst the third group consists of the ratios determining the level of debt (asset coverage ratio, durability of the financial structure, total debt).

Financial and operational risks are assessed by a group of profitability, liquidity and debt ratios. Although the formulas listed in the Table 1 are well known, there is a need to present them so that the obtained results could be unambiguously interpreted.

Table 1. Formulas of the ratios

\begin{tabular}{|c|c|c|}
\hline Name of the ratio & $\begin{array}{l}\text { Abbreviate } \\
\text { d name }\end{array}$ & Formula \\
\hline \multicolumn{3}{|c|}{ Profitability ratios } \\
\hline Operating profitability of assets & ROA & Operating Profit / Average Assets \\
\hline Return on Equity & ROE & Net profit/Average Equity \\
\hline Return on Net Sales & ROSN & Zysk Netto/Przychody Ogółem \\
\hline Return on Sales Basics & ROSB & Profit On Sales/Sales Revenue \\
\hline Economic Return on Sales & ERS & $\begin{array}{c}\text { (Operating Profit + Amortization+Depreciation) } / \text { (Sales } \\
\text { Revenue + Other Operating Income) }\end{array}$ \\
\hline \multicolumn{3}{|r|}{ Liquidity ratios } \\
\hline Current Liquidity & $\mathrm{CL}$ & $\begin{array}{c}\text { (Current Assets - Receivables due to Supplies and Services } \\
\text { over } 12 \text { months) / Short-term Liabilities) }\end{array}$ \\
\hline Quick Liquidity & QL & $\begin{array}{l}\text { (Short-term investments +Receivables due to Supplies and } \\
\text { Services over } 12 \text { months)/Short-term Liabilities }\end{array}$ \\
\hline Cash Flow & $\mathrm{CF}$ & Short-term investments/Short-term Liabilities \\
\hline $\begin{array}{l}\text { Short-term receivables payment } \\
\text { period }\end{array}$ & SRPP & (Average Short-Term Receivables * 365)/Sales Revenue \\
\hline Payables payment period & PPP & (Average Short-Term Payables*365)/Sales Revenue \\
\hline Inventory Turnover & IT & (Average Inventory*365)/Sales Revenue \\
\hline \multicolumn{3}{|r|}{ Liability ratios } \\
\hline Asset Coverage Ratio & ACR & $\begin{array}{l}\text { (Equity + Long-term Provisions)/(Fixed Assets +Receivables } \\
\text { due to Supplies and Services over } 12 \text { months) }\end{array}$ \\
\hline $\begin{array}{l}\text { Durability of the financing } \\
\text { structure }\end{array}$ & DFS & $\begin{array}{c}\text { (Equity+Long- term Liabilities + Long-term } \\
\text { Provisions)/(Fixed Assets +Receivables due to Supplies and } \\
\text { Services over } 12 \text { months) }\end{array}$ \\
\hline Debt Ratio & DR & Total Debt / Total Assets \\
\hline \multicolumn{3}{|c|}{ Dynamic financial liquidity ratios } \\
\hline Cash Efficiency of Sales & OCS & Operating Cash Flow/Sales Revenue \\
\hline Cash Efficiency of Assets & $\mathrm{CE}$ & Operating Cash Flow/Average Assets \\
\hline
\end{tabular}

Source: own elaboration based on T. Waśniewski, W. Skoczylas: Teoria i praktyka analizy finansowej w przedsiębiorstwie [Theory and Practice of Financial Analysis in an Enterprise], FRR w Polsce, Warszawa 2004, pp. 310-318. E. Mioduchowska-Jaroszewicz: Metody i kierunki analizy wypłacalności przedsiębiorstw [Methods and Directions of Solvency Analysis of Enterprises], Wyd. Uniwersytetu Szczecińskiego, Szczecin 2005, pp. 73-76.

The set of indicators compiled in Table 1 contains specially selected indicators allowing to assess all areas of a company's operations. Above all, the effectiveness of management on an accrual (profitability ratios) and cash basis (cash flow indicators), long- and short-term financial liquidity in a static approach (financial liquidity ratios, coverage of fixed assets with equity and long-term provisions, durability of financing structure, payment period of short-term receivables, payment period of liabilities, turnover rate) and in a dynamic approach (cash-flow indicators) and debt level (total debt ratio).

The study was divided into two parts. The first part focuses on the results of the ratios calculated on the basis of the results of 102 non-financial enterprises listed on the the Warsaw Stock Exchange in Poland according to the data compiled in accordance with IFRS (International Financial Reporting Standards). The second part of the research aims to analyze the results of sectoral indicators published in the annual publication, appearing since 2005, on the basis of 
the data compiled according to PKD (Polish Classification of Enterprises) based on the data compiled according to the Accounting Act. The calculations of the selected indicators include financial data of about 40000 enterprises (in 2013 there were 37 119, 2014 - 47 864, in 2015 52 111, and in 2016 - 42 406). The number of the data considered in the study also depends on the access to the data, whilst the number of enterprises varies depending on the type of an indicator.

The analysis of variability of financial results of enterprises from a sectoral perspective The following research hypotheses were formulated in order to analyze the variability of the financial results of sector-varied enterprises.

\section{H1: The profitability ratios are more variable than the liquidity ratios.}

Based on the research on the variability of indicators, it should be pointed out that the most variable sectoral means are the profitability ratios, whilst the value of the coefficient of variation is usually significantly above unity (quite often it is several times higher) or very rarely close to unity. This conclusion relates to the value of indicators calculated on a large group of 16744 enterprises. This means that comparing the profitability ratios of the analyzed enterprise with the average sectoral profitability of any type is inconclusive. The analysis of the variability of financial liquidity ratios (e.g. see the variability of the liquidity ratios in 2014 according to IFRS), calculated on the basis of the data compiled in accordance with IFRS and the Accounting Act, showed that there is a lower variability of the results compared to profitability ratios (see Table 1, Table 5, the values of the coefficient of variation in 2010-2016). The variability of the results seems to be due to both the standards that affect the value of the financial liquidity ratio and the principles of the pursuit of economic activity based on the trade credit policy. The norms, i.e., the optimal values within which the values of liquidity ratios can vary, lead to the situation where the variability of liquidity ratios is less diversified than the variability of profitability ratios, which are not limited by any ranges of values. The variability of cash flow results is also affected by the cash cycle which relies on market conditions. The period of debt collection and the payment period of liabilities resulting from the settlements with suppliers and services are strictly dependent on the standards adopted by entrepreneurs. Thus, one can notice that there is smaller variability of indicators of the payment period of short-term receivables and payment of liabilities. The most variable indicator among the liquidity ratios is the inventory turnover rate. The hypothesis was positively verified.

H2: The debt ratio is characterized by the highest stability of results. Which indicators are subject to the smallest fluctuations?

The values of the coefficient of variation of debt ratios reached a level that ranged from 0.4 to 1.0, which means that the variability is still high, but the spread of averages is smaller than with other indicators. The debt ratio calculated on the basis of the data compiled in accordance with IFRS is most often around 0.4 (the coefficient of variation of the debt ratio in 2013-2014 according to IFRS). For the years 2010-2016, the analysis of the variability of total debt showed that it was characterized by similar values as those calculated for the data according to the Accounting Act. The hypothesis was positively verified - the level of debt is characterized by the highest stability of results and is subject to the smallest fluctuations.

\section{H3: The usefulness/variability of sectoral ratios does not depend on the type of information used to calculate their value.}

The study used a maximum of 16 indicators. Five profitability ratios, six liquidity ratios, three debt ratios and two dynamic liquidity ratios were used in the Author's own research, based on the financial data drawn from the financial statements of the companies listed on the WSE, prepared in accordance with IFRS. Whilst the coefficient of variation calculated based on other research (according to the financial data from the Accounting Act) was calculated using fourteen indicators. The comparative analysis of the values of variability indicators shows the 
same volatility of indicators calculated on the basis of the Accounting Act as well as in accordance with IFRS.

H4: From a sectoral perspective, the variability of financial results makes it impossible to use them properly in the assessment of the financial standing of enterprises.

When assessing the financial situation using the methods of financial analysis, it is important to make comparisons referring analytical results to sectoral averages. Using the sectoral averages, one interprets the correctness of the calculated indicators and one takes into account the deviations from the average values. The studies carried out in terms of time and space indicate a very high or extremely high variability of financial results presented in the Author's own and published research (Tables 1-15, appendix), which is indicative of the low cognitive value of the inference analysis carried out in this way. The research hypothesis was verified positively.

H5: Financial results of particular sectors differ due to the lack of stability in shaping financial results. Which sectors are characterized by greater volatility of financial results? To meet the aim of the study, 19 sectors from listed companies and 18 sectors from the PKD classification (Classification of Business Activities in Poland) were used on the basis of their similarity to the division of the listed companies. All the sectors assessed on the basis of the annual reports, prepared in accordance with IFRS and the Accounting Act, are characterized by high variability of financial results. Thus, it can not be confirmed that the sectors differ as to whether there is stability in the shaping of the financial indicators. The analysis of the volatility of the indicators shows that the sector of crude petroleum and natural gas (PNG) is characterized by the highest coefficients of variation for each indicator tested and for each year under review. The sector was identified according to the PKD classification. Such a clear difference in the variability of the results was not noticed when compared to the value of the coefficient of variation calculated for the sectors of the WSE in Poland. The hypothesis was verified negatively.

H6: The ratios based on cash data are more stable than those based on accrual data.

It should be emphasized that this research hypothesis was verified only on the basis of the financial data compiled according to IFRS for the listed companies in the years 2013-2014. Two cash indicators were tested in the study of the variability of the results: cash efficiency of sales (Operating Cash Flow/Sales Revenue) and cash efficiency of assets (Operating Cash Flow/Average Assets). The comparison of the coefficient of variation of the cash indicators with the coefficient of variation of the accrual data shows that the cash ratios are characterized by greater variability than the accrual indicators. Almost $100 \%$ of the values of the coefficients of variation of cash indicators are above 0.5 , meaning their usefulness for sectoral comparisons is very limited as they are characterized by extremely high variability of results.

\section{Final Conclusions}

The analysis of the assessment of the usefulness of the sectoral means of the enterprises shows that it is negative. The research conducted in the article confirmed the conclusions of the research carried out by other researchers from various countries and economies. Every analysis of material and non-material results requires making comparisons, which means that the lack of comparisons makes it impossible to draw conclusions from the assessments of the financial situation of enterprises. Nevertheless, one must count, evaluate, compare and use different methods and tools so that the results could be confronted with each other in order to verify them. There are no ideal evaluation tools, as there are no excellent sources of information and there will never be perfect solutions, norms of indicators that can be adjusted to a given sector, department or group of companies. The assessment of financial results using comparisons in space should be carried out in a narrow dimension, which means that financial results of enterprises with the same specificity should be taken into consideration and compared to show the real financial standing of companies. The conducted analyses on the basis of the sectoral 
data of the listed companies confirmed that the smaller the number of enterprises is compared, the less variable the results are.

\section{Literature:}

Bahiraie, A., Azhar, A.K.M., \& Ibrahim, N.A. (2010). Logistic robust method to new generalized geometric credit risk approach. Applied Mathematical Sciences 4(2): pp. 51-64.

Beaver, W.H. (1966). Financial Ratios as Predictors of Failure. Journal of Accounting Research 4: pp. 71111.https://doi.org/10.2307/2490171

Bernstein, L.A., Wild, J.J. (1999). Financial statement analysis theory. USA: McGrawHill.

Cowen, S.S., Hoffer, J.A. (1982). Usefulness of financial ratios in a single industry. Journal of Business Research 10(1): pp.103-118. https://doi.org/10.1016/0148-2963(82)90020-0

Deakin, E.B. (1976). Distributions of financial accounting ratios: Some empirical evidence. The Accounting Review 51(1): pp. 90-96.

Dudycz T., Hamrol M., Skoczylas W., Niemiec A. (2005). Finansowanie wskaźniki sektorowe - pomocy przy analizie finansowej i ocenie zdolności przedsiębiorstwa do kontynuacji działalności. Rachunkowość 3.

Dudycz T., Skoczylas W. (2007), Wykorzystanie wskaźników sektorowych do oceny przedsiębiorstwa. Rachunkowość 7.

Dudycz T., Skoczylas W. (2008). Wskaźniki sektorowe za rok 2006. Rachunkowość 5.

Dudycz T., Skoczylas W. (2009). Wskaźniki sektorowe za rok 2007. Rachunkowość 6.

Dudycz T., Skoczylas W. (2010). Ocena sytuacji finansowej sektorów w roku 2008. Rachunkowość 6.

Dudycz T., Skoczylas W. (2011). Sektorowe wskaźniki finansowe za rok 2009 i ich porównywalności. Rachunkowość 4.

Dudycz T., Skoczylas W. (2012). Sytuacja finansowa przedsiębiorstw według sekcji i działów w roku 2010 cz. I, Rachunkowość 3.

Dudycz T., Skoczylas W. (2013). Wskaźniki finansowe przedsiębiorstw według działów (branż) za rok 2011. Rachunkowość 3.

Dudycz T., Skoczylas W. (2014). Sytuacja finansowa przedsiębiorstw według działów (branż) w 2012 rok. Rachunkowość 3.

Dudycz T., Skoczylas W. (2015). Wskaźniki finansowe przedsiębiorstw według działów (sektorów) za rok 2013. Rachunkowość 3.

Dudycz T., Skoczylas W. (2016). Sektorowe wskaźniki finansowe: wskaźniki finansowe przedsiębiorstw według działów (sektorów) za rok 2014. Rachunkowość 3.

Dudycz T., Skoczylas W. (2017). Wskaźniki finansowe przedsiębiorstw według działów (sektorów) za 2016 rok. Rachunkowość 4.

Dudycz T., Skoczylas W.(2006). Wskaźniki sektorowe w roku 2004. Rachunkowość 5.

Ezzamel, M., Mar-Molinero, C. (1990). The distributional properties of financial ratios in UK manufacturing companies. Journal of Business Finance \& Accounting 17(1): pp. 1-29. https://doi.org/10.1111/j.14685957.1990.tb00547.x

Frecka, T.J., Hopwood, W.S. (1983). The effects of outliers on the cross-sectional distributional properties of financial ratios. Accounting Review 58(1): pp. 115-128.

Hamrol M. (2013). Niedoceniane aspekty badania sprawozdania finansowego przedsiębiorstw. Zeszyty Naukowe Uniwersytetu Szczecińskiego 760. Finanse, rynki finansowe, ubezpieczenia 59: pp. 123-132.

Kane, G.D., Richardson, F.M., Meade, N.L. (1998). Rank transformations and the prediction of corporate failure. Contemporary Accounting Research 15(2): pp. 145-166. https://doi.org/10.1111/j.1911-3846.1998.tb00553.x

Lev, B., Sunder, S. (1979). Methodological issues in the use of financial ratios. Journal of Accounting and Economics 1(3): 187-210. https://doi.org/10.1016/0165-4101(79)90007-7

Linares-Mustarós, S., Farreras-Noguer, M.A., Ferrer-i-Comalat, J.C., Rabaseda-Tarrés, J. (2013). Una nueva ratio sectorial: La ratio de retorno líquido. Cuadernos del CIMBAGE 15: pp. 57-72.

Lizarraga Dallo, F. (1996). Modelos multivariantes de previsión del fracaso empresarial: Una aplicación a la realidad de la información contable espańola. Doctoral thesis, Universidad Pública de Navarra.

Martikainen, T., Perttunen, J., Yli-Olli, P., Gunasekaran, A. (1995). Financial ratio distribution irregularities: Implications for ratio classification. European Journal of Operational Research 80(1): pp. 34-44. https://doi.org/10.1016/0377-2217(93)E0134-J

Mcleay, S., Omar, A. (2000). The sensitivity of prediction models to the non-normality of bounded and unbounded financial ratios. The British Accounting Review 32(2): pp. 213-230. https://doi.org/10.1006/bare.1999.0120

Bednarz T., Mioduchowska-Jaroszewicz E., Ziółkowska E. (2015), Analiza poziomu zadłużenia przedsiębiorstw na przykładzie „dobrych” i ,złych” firm w latach 2010-2012. rev. ed. Zimny A. Wybrane problemy $i$ wyzwania gospodarcze. Ujęcie interdyscyplinarne: Państwowa Wyższa Szkoła Zawodowa w Koninie pp. 203-214. 
Bednarz T., Mioduchowska-Jaroszewicz E., Ziółkowska E. (2015), Diagnoza pozycji finansowej spółek giełdowych metodą quick testu. Zeszyty Naukowe 810. Studia i Prace Wydziału Nauk Ekonomicznych $i$ Zarzadzania 35: Uniwersytet Szczeciński pp. 57-70.

Mioduchowska-Jaroszewicz E. (2005), Metody i kierunki analizy wypłacalności przedsiębiorstw: Uniwersytetu Szczecińskiego pp. 73-76.

Bednarz T., Mioduchowska-Jaroszewicz E., Ziółkowska E. (2015), Płynność finansowa w spółkach giełdowych w latach 2010-2012. rev. ed. Zimny A. Wybrane problemy $i$ wyzwania gospodarcze. Ujęcie interdyscyplinarne: Państwowa Wyższa Szkoła Zawodowa w Koninie pp. 187-202.

Mioduchowska-Jaroszewicz E. (2015), The Level of Depreciation in Cash w: „Knowledge - Economy - Society. In the Development and Challenges of Modern Economies, Finance and Information Technology". Rev.ed. Malina A. , Oczkowska R., Kaczmarek J. Foundation of the Cracow University of Economics: Chapter 20, pp. 213-224. Mioduchowska-Jaroszewicz E. (2015), Zakłócenia porównywalności w ocenie kondycji finansowej przedsiębiorstw. rev.ed.Kaczmarek J., Szymla W.: Teoria i praktyka zarządzania w obliczu nowych wyzwań: Fundacja Uniwersytetu Ekonomicznego w Krakowie, pp. 295-306.

Nikolic, N., Zarkic-Joksimovic, N., Stojanovski, D., Joksimovic, I. (2013). The application of brute force logistic regression to corporate credit scoring models: Evidence from Serbian financial statements. Expert Systems with Applications, 40(15): pp. 5932-5944. https://doi.org/10.1016/j.eswa.2013.05.022

Nissim, D., Penman, S.H. (2001). Ratio Analysis and Equity Valuation: From Research to Practice. Review of Accounting Studies, 6: pp. 109-154. https://doi.org/10.1023/A:1011338221623

Oliveras, E., Moya, S. (2005). La utilización de los datos sectoriales para complementar el análisis de estados financieros. Revista de contabilidad y dirección, 2: pp. 53-69.

Rondós-Casas, E., Linares-Mustarós S., Farreras-Noguer Ŕ. M. (2018). Expansion of the current methodology for the study of the short-term liquidity problems in a sector, Intangible Capital IC, 14(1): pp. 25-34. https://doi.org/10.3926/ic.1085.

So, J.C. (1987). Some empirical evidence on the outliers and the non normal distribution - of financial ratios. Journal of Business Finance \& Accounting, 14(4): pp. 483-496. https://doi.org/10.1111/j.14685957.1987.tb00108.x

Sudarsanam, P.S., Taffler, R.J. (1995). Financial ratio proportionality and inter-temporal stability: An empirical analysis. Journal of banking \& finance, 19(1): pp. 45-60. https://doi.org/10.1016/0378-4266(94)00044-4

Waśniewski T., Skoczylas W. (2004), Teoria i praktyka analizy finansowej $w$ przedsiębiorstwie: Fundacja Rozowju Rachunkowości w Polsce, pp. 310-318.

Watson, C.J. (1990). Multivariate distributional properties, outliers, and transformation of financial ratios. The Accounting Review, 65(3): pp. 682-695. 


\section{APPENDIX}

Table 1

The value of the coefficient of variation of profitability ratios in 2013-2014 according to IFRS

\begin{tabular}{|l|l|l|l|l|l|l|l|l|l|l|}
\hline \multirow{2}{*}{ Name of the sector according toWSE } & \multicolumn{2}{|c|}{ ROA } & \multicolumn{2}{c|}{ ROE } & \multicolumn{2}{c|}{ ROSN } & \multicolumn{2}{c|}{ ROSB } & \multicolumn{2}{c|}{ ERS } \\
\cline { 2 - 10 } & $\mathbf{2 0 1 3}$ & $\mathbf{2 0 1 4}$ & $\mathbf{2 0 1 3}$ & $\mathbf{2 0 1 4}$ & $\mathbf{2 0 1 3}$ & $\mathbf{2 0 1 4}$ & $\mathbf{2 0 1 3}$ & $\mathbf{2 0 1 4}$ & $\mathbf{2 0 1 3}$ & $\mathbf{2 0 1 4}$ \\
\hline Raw Materials & 1.05 & 0.61 & 1.14 & 0.58 & 1.15 & 0.62 & 1.08 & 0.65 & 1.11 & 0.94 \\
\hline Automotive & 1.41 & 1.42 & 1.86 & -3.28 & 3.49 & -2.24 & 0.05 & 0.04 & 1.98 & 2.40 \\
\hline Metal & 2.75 & 1.15 & 5.24 & 1.72 & 1.86 & 1.74 & -4.36 & 11.26 & 1.42 & 0.91 \\
\hline Media & 1.83 & 22.01 & 2.22 & -2.6 & 2.20 & -2.71 & -6.14 & -5.62 & 1.86 & -2.84 \\
\hline Light Industry & 0.87 & 1.15 & 1.09 & 1.07 & 1.76 & 2.05 & 1.96 & 1.74 & 1.01 & 1.99 \\
\hline Wholesale & 1.86 & 4.30 & 3.51 & -6.39 & 2.32 & 6.38 & 2.17 & 2.54 & 3.99 & 3.99 \\
\hline Construction & 1.65 & 2.03 & 1.63 & 1.66 & 1.74 & 13.16 & -7.10 & -9.71 & 1.70 & 1.80 \\
\hline Chemical & 0.96 & 1.28 & 1.30 & 1.84 & 2.50 & 2.51 & 0.83 & 0.62 & 2.35 & 2.48 \\
\hline Wood & 1.97 & 1.59 & -19.73 & 1.24 & -4.95 & 3.73 & 5.86 & 1.16 & 1.25 & 1.44 \\
\hline Electromechanical & 0.85 & 0.73 & 0.76 & 0.74 & 0.70 & 1.15 & 1.69 & 0.92 & 1.65 & 0.82 \\
\hline Pharmaceutical & 0.92 & 1.81 & 1.66 & 5.93 & 8.45 & 9.20 & 0.47 & 1.65 & 0.41 & 1.48 \\
\hline Energy and petroleum & 2.00 & 1.67 & 0.86 & 1.00 & 0.93 & 1.13 & -6.43 & -4.20 & 11 & 49 \\
\hline Hotels and restaurants & 0.90 & 0.91 & 0.67 & -4.00 & 1.00 & 1.25 & 0.69 & 0.69 & 0.53 & 0.71 \\
\hline Telecommunication & -2.88 & - & -2.91 & 3.64 & -6.00 & -4.03 & -2.55 & -2.98 & 17.50 & 2.58 \\
\hline Retail & 0.20 & 0.63 & 0.00 & 0.67 & 0.00 & -8.00 & 0.14 & 1.78 & 0.00 & -14.00 \\
\hline Real Estate Development & 1.50 & 1.50 & -9.00 & -4.00 & -3.78 & 19.67 & 2.13 & 3.70 & 3.40 & -5.01 \\
\hline Food & 2.25 & 0.83 & 3.63 & 1.17 & 7.00 & 1.00 & 1.20 & 1.20 & 1.60 & 0.71 \\
\hline Plastics & 0.67 & 0.40 & 0.88 & 1.47 & 0.83 & 1.17 & 1.09 & 1.44 & 0.64 & 0.56 \\
\hline IT & 1.29 & 1.00 & 7.40 & 1.38 & 1.50 & 2.00 & 1.32 & 1.29 & 0.93 & 0.92 \\
\hline Construction & 2.00 & - & 1.42 & 1.00 & 1.25 & 1.00 & -4.27 & -4.86 & 7.00 & -3.79 \\
\hline
\end{tabular}

Source: own elaboration based on the financial statements of listed companies prepared in accordance with IASC

Table 2

The value of the coefficient of variation of liquidity ratios in 2013-2014 according to IFRS

\begin{tabular}{|c|c|c|c|c|c|c|c|c|c|c|c|c|}
\hline \multirow{2}{*}{$\begin{array}{l}\text { Name of the sector } \\
\text { according toWSE }\end{array}$} & \multicolumn{2}{|c|}{ CL } & \multicolumn{2}{|c|}{ QL } & \multicolumn{2}{|c|}{ CF } & \multicolumn{2}{|c|}{ SRPP } & \multicolumn{2}{|c|}{ PPP } & \multicolumn{2}{|c|}{ DR } \\
\hline & 2013 & 2014 & 2013 & 2014 & 2013 & 2014 & 2013 & 2014 & 2013 & 2014 & 2013 & 2014 \\
\hline Raw Materials & 0.78 & 0.61 & 1.15 & 1.15 & 1.14 & 1.15 & 1.15 & 1.15 & 0.65 & 0.59 & 0.94 & 0.58 \\
\hline Automotive & 0.37 & 0.37 & 0.28 & 1.40 & 1.01 & 1.40 & 0.23 & 0.01 & 0.5 & 0.07 & 0.35 & 0.24 \\
\hline Metal & 1.00 & 0.59 & 0.64 & 0.07 & 1.40 & 1.25 & 3.16 & 2.33 & 1.44 & 2.72 & 0.61 & 0.74 \\
\hline Media & 0.85 & 1.46 & 1.04 & 1.92 & 1.94 & 2.27 & 1.41 & 1.55 & 1.68 & 1.91 & 1.68 & 1.66 \\
\hline Light Industry & 2.44 & 0.62 & 2.43 & 1.04 & 2.30 & 0.57 & 0.76 & 1.04 & 0.53 & 0.35 & 0.41 & 0.44 \\
\hline Wholesale & 0.89 & 0.79 & 0.90 & 0.83 & 2.46 & 2.38 & 1.23 & 1.03 & 3.16 & 2.09 & 0.68 & 0.69 \\
\hline Construction & 0.43 & 0.50 & 0.80 & 0.79 & 1.10 & 1.85 & 1.08 & 1.21 & 2.89 & 2.66 & 0.98 & 0.96 \\
\hline Chemical & .65 & 0.57 & 1.28 & 1.16 & 1.86 & 1.92 & 2.18 & 0.91 & 1.89 & 1.52 & 0.77 & 0.86 \\
\hline Wood & 0.86 & 1.08 & 1.11 & 1.15 & 1.86 & 2.04 & 1.21 & 1.09 & 0.65 & 0.85 & 0.57 & 0.30 \\
\hline Electromechanical & 0.76 & 0.89 & 0.77 & 0.86 & 1.31 & 1.37 & 4.29 & 0.49 & 3.97 & 0.67 & 4.43 & 0.89 \\
\hline Pharmaceutical & 0.45 & 1.13 & 0.65 & 0.55 & 0.74 & 0.76 & 0.58 & 0.49 & 0.77 & 1.04 & 1.34 & 1.26 \\
\hline $\begin{array}{l}\text { Energy and } \\
\text { petroleum }\end{array}$ & 0.47 & 0.79 & 0.57 & 0.97 & 0.93 & 1.42 & 0.56 & 0.93 & 2.48 & 2.30 & 0.96 & 0.97 \\
\hline $\begin{array}{l}\text { Hotels and } \\
\text { restaurants }\end{array}$ & 0.89 & 0.86 & 1.01 & 0.74 & 1.10 & 0.96 & 0.47 & 0.50 & 0.19 & 0.25 & 1.23 & 0.50 \\
\hline Telecommunication & 2.81 & 2.31 & 2.81 & 2.34 & 2.81 & 0.94 & 1.40 & 1.38 & 1.47 & 1.24 & 2.16 & 2.21 \\
\hline Retail & 0.01 & 8.08 & 0.06 & 11.77 & - & 38.00 & 0.15 & 3.64 & 0.09 & 3.39 & 0.01 & 3.38 \\
\hline $\begin{array}{l}\text { Real Estate } \\
\text { Development }\end{array}$ & 1.58 & 1.58 & 1.45 & 1.14 & 1.18 & 1.16 & 3.45 & 3.85 & 1.98 & 2.13 & 0.95 & 0.93 \\
\hline Food & 0.51 & 1.64 & 0.96 & 3.35 & 1.29 & 1.57 & 0.82 & 0.81 & 0.65 & 0.75 & 0.69 & 0.74 \\
\hline Plastics & 0.10 & 0.18 & 0.19 & 0.13 & 1.56 & 1.43 & 0.37 & 0.07 & 0.14 & 0.15 & 0.53 & 0.41 \\
\hline IT & 1.25 & 1.37 & 1.36 & 1.55 & 1.43 & 1.75 & 0.54 & 0.47 & 0.59 & 0.82 & 2.60 & 3.46 \\
\hline
\end{tabular}

Source: own calculations based on the financial statements of listed companies

Table 3

The value of the coefficient of variation of liability and dynamic financial liquidity ratios in 2013-2014 according to IFRS

\begin{tabular}{|c|c|c|c|c|c|c|c|c|c|c|}
\hline \multirow{2}{*}{$\begin{array}{c}\text { Name of the sector } \\
\text { according toWSE }\end{array}$} & \multicolumn{2}{|c|}{ ACR } & \multicolumn{2}{|c|}{ DFS } & \multicolumn{2}{c|}{ DR } & \multicolumn{2}{|c|}{ OCS } & \multicolumn{2}{c|}{ CE } \\
\cline { 2 - 10 } & 2013 & 2014 & 2013 & 2014 & 2013 & 2014 & 2013 & 2014 & 2013 & 2014 \\
\hline
\end{tabular}




\begin{tabular}{|l|l|l|l|l|l|l|l|l|l|l|}
\hline Raw Materials & 0.58 & 0.59 & 0.58 & 0.58 & 0.59 & 0.59 & 0.75 & 1.03 & 0.67 & 1.01 \\
\hline Automotive & 0.47 & 0.61 & 0.38 & 0.36 & 1.41 & 0.19 & 1.61 & 1.88 & 1.41 & 1.41 \\
\hline Metal & 0.30 & 0.34 & 0.29 & 0.31 & 0.55 & 0.44 & 1.3 & 3.11 & 0.67 & 0.74 \\
\hline Media & 0.44 & 0.76 & 0.39 & 0.77 & 0.74 & 0.68 & 9.62 & -9.39 & 2.06 & 2.04 \\
\hline Light Industry & 0.14 & 0.26 & 0.15 & 0.26 & 0.69 & 0.65 & 2.20 & 3.36 & 1.87 & 14.42 \\
\hline Wholesale & 0.74 & 0.77 & 0.74 & 0.73 & 0.4 & 0.53 & 1.61 & 2.20 & 0.97 & 1.81 \\
\hline Construction & 0.73 & 0.73 & 0.39 & 0.37 & 0.43 & 0.46 & -6.62 & -4.33 & 1.26 & 1.66 \\
\hline Chemical & 0.60 & 0.53 & 0.39 & 0.35 & 0.39 & 0.38 & 2.48 & 2.31 & 1.40 & 0.69 \\
\hline Wood & 0.55 & 0.56 & 0.40 & 0.55 & 0.33 & 0.31 & 1.54 & 1.51 & 0.77 & 0.96 \\
\hline Electromechanical & 0.89 & 0.40 & 0.86 & 0.32 & 1.37 & 0.63 & 0.49 & 1.15 & 0.67 & 0.76 \\
\hline Pharmaceutical & 0.29 & 0.43 & 0.26 & 0.35 & 0.61 & 0.55 & 0.99 & 0.76 & 1.11 & 0.95 \\
\hline Energy and petroleum & 0.24 & 0.21 & 0.13 & 0.10 & 0.41 & 0.52 & - & -6.7 & 1.00 & 1.17 \\
\hline Hotels and restaurants & 0.32 & 0.35 & 0.08 & 0.07 & 0.65 & 0.67 & 0.44 & 0.71 & 0.50 & 0.40 \\
\hline Telecommunication & 0.56 & 0.41 & 0.53 & 0.36 & 0.88 & 0.84 & -2.92 & 13.67 & -10.00 & 2.00 \\
\hline Retail & 0.01 & 0.40 & 0.01 & 0.09 & 0.08 & 1.09 & 0.00 & -10.19 & 0.20 & 2.33 \\
\hline $\begin{array}{l}\text { Real Estate } \\
\text { Development }\end{array}$ & 1.86 & 2.42 & 1.92 & 2.34 & 1.55 & 3.62 & -3.05 & -3.31 & 3.00 & 3.00 \\
\hline Food & 0.56 & 0.66 & 0.35 & 0.44 & 0.61 & 0.74 & 1.25 & 1.20 & 1.40 & 0.86 \\
\hline Plastics & 0.21 & 0.20 & 0.13 & 0.12 & 0.12 & 0.08 & 0.69 & 0.50 & 0.45 & 0.33 \\
\hline IT & 2.06 & 0.51 & 1.98 & 0.47 & 0.56 & 0.41 & 1.00 & 2.14 & 1.20 & 1.11 \\
\hline
\end{tabular}

Source: own calculations based on the financial statements of listed companies

Table 4

Sectors' names with their abbreviations

\begin{tabular}{|l|l|}
\hline The name of the sector according to PKD* & $\begin{array}{l}\text { Abbre } \\
\text { v. }\end{array}$ \\
\hline Production of food products & F \\
\hline Manufacture of beverages & B \\
\hline Manufacture of textile articles & T \\
\hline Manufacture of chemicals and chemical articles & Ch \\
\hline $\begin{array}{l}\text { Manufacture of basic pharmaceutical substances, medicines and other } \\
\text { pharmaceutical products }\end{array}$ & Ph \\
\hline Manufacture of computers and electronic and optical equipment & \\
\hline Manufacture of electronic equipment & C \\
\hline Manufacture of motor vehicles & E \\
\hline Wholesale trade excluding motor vehicle & VEH \\
\hline Retail trade excluding motor vehicle & WS \\
\hline Telecommunication & RS \\
\hline Computer programming and computer consultancy and other related activities & TEL \\
\hline Accommodation & PROG \\
\hline Food service activity & ACC \\
\hline Building works related to erection of residential and non-residential buildings & FS \\
\hline Works related to construction of water and land projects & BUD \\
\hline Mining of hard coal and lignite & ENG \\
\hline Extraction of crude petroleum and natural gas & HCL \\
\hline Source: own elaboration & PNG \\
\hline
\end{tabular}

Source: own elaboration

*PKD - Classification of Business Activities in Poland

Table 5

The value of the coefficient of variation of profitability ratios in 2013-2014 calculated according to the Accounting Act

\begin{tabular}{|l|l|l|l|l|l|l|l|l|l|l|}
\hline \multirow{4}{*}{$\begin{array}{c}\text { Sector } \\
\begin{array}{c}\text { according } \\
\text { PKD* }\end{array}\end{array}$} & \multicolumn{3}{|c|}{ ROA } & \multicolumn{2}{c|}{ ROE } & \multicolumn{2}{c|}{ ROSN } & \multicolumn{2}{c|}{ ROSB } & \multicolumn{2}{c|}{ ERS } \\
\cline { 2 - 12 } & $\mathbf{2 0 1 3}$ & $\mathbf{2 0 1 4}$ & $\mathbf{2 0 1 3}$ & $\mathbf{2 0 1 4}$ & $\mathbf{2 0 1 3}$ & $\mathbf{2 0 1 4}$ & $\mathbf{2 0 1 3}$ & $\mathbf{2 0 1 4}$ & $\mathbf{2 0 1 3}$ & $\mathbf{2 0 1 4}$ \\
\hline $\mathrm{F}$ & 1.35 & 1,41 & 1.53 & 1.54 & 1.62 & 1.50 & 1.61 & 1.50 & 1.03 & 1.06 \\
\hline $\mathrm{B}$ & 1.47 & 1.71 & 1.88 & 1.89 & 1.80 & 1.81 & 1.66 & 1.81 & 1.08 & 1.01 \\
\hline
\end{tabular}




\begin{tabular}{|l|l|l|l|l|l|l|l|l|l|l|}
\hline T & 1.54 & 1.19 & 1.53 & 1.43 & 1.58 & 1.52 & 1.49 & 1.52 & 1.10 & 0.99 \\
\hline Ch & 1.30 & 1.21 & 1.55 & 1.37 & 1.52 & 1.26 & 1.30 & 1.26 & 1.06 & 0.93 \\
\hline Ph & 1.28 & 1.81 & 1.31 & 2.07 & 1.27 & 1.98 & 1.02 & 1.98 & 0.90 & 1.05 \\
\hline C & 1.60 & 1.60 & 1.72 & 1.63 & 1.60 & 1.53 & 1.60 & 1.53 & 1.36 & 1.16 \\
\hline E & 1.38 & 1.34 & 1.50 & 1.40 & 1.50 & 1.42 & 1.50 & 1.42 & 1.05 & 0.95 \\
\hline VEH & 1.16 & 1.19 & 1.42 & 1.32 & 1.40 & 1.38 & 1.35 & 1.38 & 0.97 & 0.86 \\
\hline WS & 1.42 & 1.34 & 1.60 & 1.57 & 1.58 & 1.53 & 1.56 & 1.53 & 1.22 & 1.19 \\
\hline RS & 1.72 & 1.65 & 1.89 & 1.86 & 1.80 & 1.74 & 2.33 & 1.74 & 1.31 & 1.31 \\
\hline TEL & 1.55 & 1.73 & 1.88 & 2.18 & 1.87 & 2.01 & 2.18 & 2.01 & 1.18 & 1.36 \\
\hline PROG & 2.07 & 1.98 & 2.23 & 2.04 & 2.07 & 1.93 & 2.15 & 1.93 & 1.61 & 1.43 \\
\hline ACC & 4.08 & 2.13 & 252.50 & 4.11 & 12.18 & 3.51 & 3.70 & 3.51 & 1.48 & 1.26 \\
\hline FS & 2.34 & 1.81 & 2.22 & 2.29 & 2.48 & 1.75 & 2.25 & 1.75 & 1.34 & 1.16 \\
\hline BUD & 2.48 & 2.36 & 2.75 & 2.58 & 2.36 & 2.09 & 2.23 & 2.09 & 1.83 & 1.67 \\
\hline ENG & 2.51 & 1.72 & 2.54 & 1.88 & 2.33 & 1.76 & 2.86 & 1.76 & 1.45 & 1.25 \\
\hline HCL & 12.06 & 1.38 & -2.19 & 1.12 & -1.61 & 13.64 & -2.25 & 13.64 & -2.26 & 3.69 \\
\hline PNG & -5.41 & & -1.18 & & -1.34 & - & -1.70 & - & 2.17 & \\
& & -1.21 & & -1.29 & & 18.79 & & 18.79 & & -2.04 \\
\hline
\end{tabular}

*PKD - Classification of Business Activities in Poland

Source: own study based on the financial statements of the companies

Table 6

The value of the coefficient of variation of liquidity ratios in 2013-2014 calculated according to the Accounting Act

\begin{tabular}{|c|c|c|c|c|c|c|c|c|c|c|c|c|}
\hline \multirow{2}{*}{$\begin{array}{c}\text { Sector } \\
\text { according } \\
\text { to } P K K^{*}\end{array}$} & \multicolumn{2}{|c|}{ CL } & \multicolumn{2}{|c|}{ QL } & \multicolumn{2}{|c|}{$\mathbf{C F}$} & \multicolumn{2}{|c|}{ SRPP } & \multicolumn{2}{|c|}{ PPP } & \multicolumn{2}{|c|}{ IT } \\
\hline & $\begin{array}{l}201 \\
3\end{array}$ & $\begin{array}{l}201 \\
4\end{array}$ & $\begin{array}{l}201 \\
3\end{array}$ & $\begin{array}{l}201 \\
4\end{array}$ & $\begin{array}{l}201 \\
3\end{array}$ & $\begin{array}{l}201 \\
4\end{array}$ & $\begin{array}{l}201 \\
3\end{array}$ & $\begin{array}{l}201 \\
4\end{array}$ & $\begin{array}{l}201 \\
3\end{array}$ & $\begin{array}{l}201 \\
4\end{array}$ & $\begin{array}{l}201 \\
3\end{array}$ & \begin{tabular}{|l|}
201 \\
4
\end{tabular} \\
\hline $\mathrm{F}$ & 0.68 & 0.74 & 0.78 & 0.86 & 0.68 & 0.87 & 0.71 & 0.70 & 0.67 & 0.70 & 1.03 & 1.05 \\
\hline B & 0.72 & 0.71 & 0.83 & 0.90 & 0.72 & 1.45 & 0.47 & 0.63 & 0.73 & 0.75 & 0.84 & 0.77 \\
\hline $\mathrm{T}$ & 0.85 & 0.88 & 1.02 & 1.10 & 0.85 & 1.40 & 0.55 & 0.62 & 0.79 & 0.89 & 0.83 & 0.83 \\
\hline $\mathrm{Ch}$ & 0.78 & 0.81 & 0.85 & 0.90 & 0.78 & 1.53 & 0.48 & 0.50 & 0.66 & 0.69 & 0.70 & 0.68 \\
\hline $\mathrm{Ph}$ & 0.84 & 0.87 & 1.01 & 1.02 & 0.84 & 1.43 & 0.61 & 0.63 & 0.83 & 0.80 & 0.52 & 0.55 \\
\hline $\mathrm{C}$ & 0.97 & 0.94 & 1.07 & 1.05 & 0.97 & 1.40 & 0.67 & 0.64 & 0.82 & 0.81 & 0.81 & 0.89 \\
\hline $\mathrm{E}$ & 0.73 & 0.73 & 0.77 & 0.83 & 0.73 & 1.31 & 0.56 & 0.58 & 0.74 & 0.76 & 0.72 & 0.67 \\
\hline VEH & 0.77 & 0.73 & 0.78 & 0.81 & 0.77 & 1.51 & 0.60 & 0.60 & 0.68 & 0.67 & 0.69 & 0.74 \\
\hline WS & 0.75 & 0.78 & 0.84 & 0.86 & 0.75 & 1.44 & 0.71 & 0.71 & 0.79 & 0.78 & 0.89 & 0.90 \\
\hline $\mathrm{RS}$ & 0.73 & 0.74 & 0.93 & 0.97 & 0.73 & 1.36 & 1.19 & 1.19 & 0.74 & 0.73 & 0.89 & 0.85 \\
\hline TEL & 0.86 & 0.98 & 0.93 & 1.08 & 0.86 & 1.51 & 0.87 & 0.86 & 0.82 & 0.75 & 1.12 & 1.07 \\
\hline PROG & 0.90 & 0.89 & 0.93 & 0.92 & 0.90 & 1.33 & 0.70 & 0.70 & 0.97 & 1.03 & 1.27 & 1.28 \\
\hline $\mathrm{ACC}$ & 1.11 & 1.18 & 1.23 & 1.24 & 1.11 & 1.49 & 1.00 & 0.98 & 0.96 & 1.05 & 0.97 & 0.97 \\
\hline $\mathrm{FS}$ & 1.01 & 0.93 & 1.07 & 0.97 & 1.01 & 1.27 & 1.22 & 1.24 & 0.87 & 0.96 & 0.88 & 0.91 \\
\hline BUD & 1.00 & 1.01 & 1.07 & 1.11 & 1.00 & 1.52 & 0.92 & 0.93 & 0.92 & 0.94 & 1.59 & 1.61 \\
\hline ENG & 0.71 & 0.76 & 0.82 & 0.84 & 0.71 & 1.37 & 0.70 & 0.77 & 0.78 & 0.79 & 0.99 & 1.01 \\
\hline HCL & 0.67 & 1.06 & 0.93 & 1.28 & 0.67 & 1.29 & 0.49 & 0.41 & 0.64 & 0.83 & 0.38 & 1.44 \\
\hline PNG & 0.67 & 1.13 & 0.65 & 1.16 & 0.67 & 1.24 & 1.03 & 0.53 & 1.08 & 0.99 & 0.00 & 0.97 \\
\hline
\end{tabular}

*PKD - Classification of Business Activities in Poland

Source: own study based on the financial statements of the companies

Table 7

The value of the coefficient of variation of liability ratios in 2013-2014 according to the Accounting Act

\begin{tabular}{|l|l|l|l|l|l|l|}
\hline \multirow{2}{*}{$\begin{array}{c}\text { Sector } \\
\text { according to } \\
\text { PKD* }\end{array}$} & \multicolumn{2}{|c|}{ ACR } & \multicolumn{2}{c|}{ DSF } & \multicolumn{2}{c|}{ DR } \\
\cline { 2 - 7 } & $\mathbf{2 0 1 3}$ & $\mathbf{2 0 1 4}$ & $\mathbf{2 0 1 3}$ & $\mathbf{2 0 1 4}$ & $\mathbf{2 0 1 3}$ & $\mathbf{2 0 1 4}$ \\
\hline $\mathrm{F}$ & 0.62 & 0.67 & 0.34 & 0.34 & 0.51 & 0.54 \\
\hline $\mathrm{B}$ & 0.62 & 0.63 & 0.36 & 0.32 & 0.58 & 0.56 \\
\hline $\mathrm{T}$ & 1.01 & 0.99 & 0.33 & 0.37 & 0.62 & 0.64 \\
\hline $\mathrm{Ch}$ & 0.77 & 0.78 & 0.32 & 0.35 & 0.56 & 0.60 \\
\hline $\mathrm{Ph}$ & 0.93 & 0.83 & 0.29 & 0.34 & 0.66 & 0.67 \\
\hline
\end{tabular}


*PKD - Classification of Business Activities in Poland

\begin{tabular}{|l|l|l|l|l|l|l|}
\hline C & 1.15 & 1.23 & 0.35 & 0.37 & 0.67 & 0.68 \\
\hline E & 0.83 & 0.90 & 0.36 & 0.34 & 0.56 & 0.57 \\
\hline VEH & 0.65 & 0.67 & 0.36 & 0.32 & 0.56 & 0.53 \\
\hline WS & 1.26 & 1.27 & 0.47 & 0.47 & 0.55 & 0.57 \\
\hline RS & 1.06 & 1.08 & 0.44 & 0.42 & 0.55 & 0.55 \\
\hline TEL & 1.23 & 1.05 & 0.44 & 0.43 & 0.59 & 0.61 \\
\hline PROG & 1.29 & 1.27 & 0.40 & 0.41 & 0.67 & 0.66 \\
\hline ACC & 0.66 & 0.65 & 0.26 & 0.22 & 0.65 & 0.69 \\
\hline FS & 1.05 & 1.08 & 0.38 & 0.36 & 0.67 & 0.64 \\
\hline BUD & 1.24 & 1.29 & 0.43 & 0.42 & 0.62 & 0.66 \\
\hline ENG & 1.01 & 1.01 & 0.41 & 0.42 & 0.52 & 0.57 \\
\hline HCL & 1.22 & 0.69 & 0.28 & 0.42 & 0.39 & 0.41 \\
\hline PNG & 0.69 & 1.18 & 0.52 & 0.48 & 0.81 & 0.90 \\
\hline
\end{tabular}

Source: own elaboration

Figures 1. The coefficient of variation for the return on equity, the current liquidity, the total debt ratio in the sector/department of food production in 2006-2016

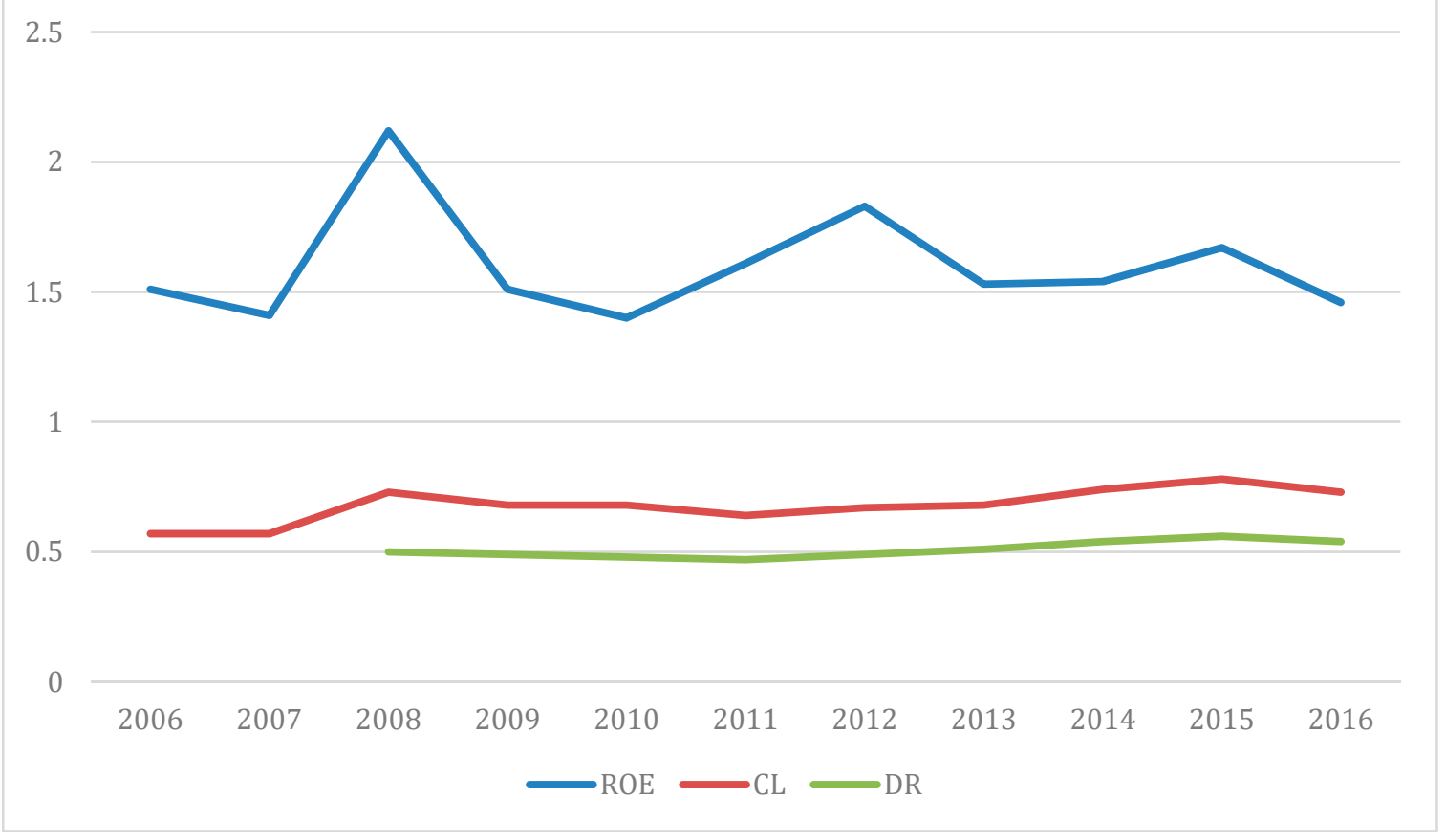

Table 8

The value of the coefficient of variation in 2016 computed based on the financial data of the Accounting Act

\begin{tabular}{|l|l|l|l|l|l|l|l|l|l|l|l|l|l|l|}
\hline $\begin{array}{l}\text { Sector } \\
\text { PKD }\end{array}$ & ROA & ROE & ROSN & ROSB & ERS & CL & QL & CF & SRPP & PPP & IT & ACR & DSF & DR \\
\hline F & 1.33 & 1.46 & 1.41 & 1.51 & 1.04 & 0.73 & 0.82 & 1.42 & 0.72 & 0.72 & 1.01 & 0.69 & 0.34 & 0.54 \\
\hline B & 1.52 & 2.24 & 2.60 & 3.23 & 1.38 & 0.86 & 0.99 & 1.59 & 0.57 & 0.71 & 0.74 & 0.70 & 0.34 & 0.58 \\
\hline T & 1.32 & 1.68 & 1.37 & 1.38 & 0.93 & 0.84 & 0.88 & 1.45 & 0.60 & 0.80 & 0.81 & 0.91 & 0.32 & 0.62 \\
\hline Ch & 1.34 & 1.27 & 1.37 & 1.22 & 0.93 & 0.78 & 0.91 & 1.43 & 0.50 & 0.65 & 0.71 & 0.77 & 0.32 & 0.60 \\
\hline Ph & 1.44 & 1.34 & 1.07 & 1.20 & 0.98 & 0.70 & 0.82 & 1.37 & 0.57 & 0.69 & 0.63 & 0.88 & 0.30 & 0.53 \\
\hline C & 2.02 & 1.87 & 1.79 & 1.99 & 1.27 & 1.00 & 1.08 & 1.49 & 0.60 & 0.85 & 0.87 & 1.14 & 0.33 & 0.67 \\
\hline E & 1.38 & 1.62 & 1.54 & 1.51 & 1.01 & 0.78 & 0.88 & 1.41 & 0.59 & 0.72 & 0.67 & 0.91 & 0.36 & 0.56 \\
\hline VEH & 1.08 & 1.35 & 1.33 & 1.29 & 0.92 & 0.65 & 0.71 & 1.30 & 0.55 & 0.68 & 0.68 & 0.67 & 0.35 & 0.52 \\
\hline WS & 1.36 & 1.53 & 1.44 & 1.45 & 1.14 & 0.76 & 0.82 & 1.41 & 0.69 & 0.76 & 0.89 & 1.33 & 0.47 & 0.56 \\
\hline RS & 1.57 & 1.81 & 1.59 & 1.93 & 1.18 & 0.73 & 0.95 & 1.34 & 1.19 & 0.72 & 0.86 & 1.08 & 0.45 & 0.54 \\
\hline TEL & 1.91 & 2.31 & 2.07 & 2.80 & 1.43 & 0.87 & 0.94 & 1.36 & 0.73 & 0.82 & 1.09 & 1.10 & 0.43 & 0.61 \\
\hline PROG & 1.89 & 1.99 & 1.74 & 1.69 & 1.40 & 0.89 & 0.92 & 1.26 & 0.68 & 1.05 & 1.30 & 1.33 & 0.41 & 0.65 \\
\hline ACC & 1.71 & 2.00 & 1.96 & 1.78 & 1.01 & 1.19 & 1.25 & 1.40 & 1.01 & 0.86 & 0.90 & 0.65 & 0.23 & 0.67 \\
\hline
\end{tabular}




\begin{tabular}{|l|l|l|l|l|l|l|l|l|l|l|l|l|l|l|} 
FS & 1.72 & 2.38 & 1.64 & 1.49 & 1.01 & 0.94 & 1.02 & 1.23 & 1.13 & 0.79 & 0.81 & 0.96 & 0.35 & 0.59 \\
\hline BUD & 2.11 & 2.11 & 1.96 & 1.94 & 1.63 & 0.91 & 1.03 & 1.44 & 0.89 & 0.87 & 1.49 & 1.32 & 0.43 & 0.62 \\
\hline ENG. & 2.63 & 2.48 & 2.61 & 3.71 & 1.66 & 0.78 & 0.87 & 1.29 & 0.80 & 0.81 & 1.03 & 1.02 & 0.41 & 0.57 \\
\hline HCL & 0.19 & 0.20 & 0.18 & 0.15 & 0.23 & 0.93 & 1.01 & 1.01 & 0.41 & 0.60 & 0.41 & 0.74 & 0.25 & 0.22 \\
\hline PNG & 18.52 & 1.66 & -1.40 & -1.31 & -1.42 & 1.47 & 1.41 & 1.28 & 0.48 & 0.56 & 0.00 & 0.24 & 0.30 & 0.95 \\
\hline
\end{tabular}

Source: own elaboration

*PKD - Classification of Business Activities in Poland

Table 9

The coefficient of variation in 2015 calculated based on the financial data of the Accounting Act

\begin{tabular}{|l|l|l|l|l|l|l|l|l|l|l|l|l|l|l|}
\hline Sector PKD* & ROA & ROE & ROSN & ROSB & ERS & CL & QL & CF & $\begin{array}{l}\text { SRP } \\
\text { P }\end{array}$ & PPP & IT & ACR & DSF & DR \\
\hline F & 1.49 & 1.67 & 1.51 & 1.69 & 1.07 & 0.78 & 0.90 & 1.47 & 0.73 & 0.72 & 1.01 & 0.72 & 0.33 & 0.56 \\
\hline B & 1.42 & 1.87 & 1.34 & 1.38 & 1.09 & 0.83 & 0.94 & 1.51 & 0.56 & 0.72 & 0.78 & 0.71 & 0.38 & 0.59 \\
\hline T & 1.49 & 1.60 & 1.42 & 2.13 & 1.09 & 0.81 & 0.97 & 1.32 & 0.62 & 0.80 & 0.92 & 0.99 & 0.28 & 0.63 \\
\hline Ch & 1.29 & 1.31 & 1.23 & 1.26 & 0.91 & 0.81 & 0.90 & 1.49 & 0.53 & 0.69 & 0.69 & 0.75 & 0.31 & 0.59 \\
\hline Ph & 1.51 & 1.75 & 1.55 & 1.34 & 1.10 & 0.82 & 0.94 & 1.41 & 0.52 & 0.69 & 0.57 & 0.81 & 0.30 & 0.68 \\
\hline C & 1.45 & 1.57 & 1.48 & 1.77 & 1.17 & 0.98 & 1.10 & 1.44 & 0.67 & 0.88 & 0.77 & 1.07 & 0.34 & 0.70 \\
\hline E & 1.24 & 1.46 & 1.38 & 1.42 & 0.89 & 0.74 & 0.80 & 1.34 & 0.56 & 0.72 & 0.68 & 0.88 & 0.35 & 0.58 \\
\hline VEH & 1.19 & 1.33 & 1.38 & 1.49 & 1.11 & 0.70 & 0.82 & 1.37 & 0.56 & 0.67 & 0.73 & 0.71 & 0.36 & 0.54 \\
\hline WS & 1.39 & 1.55 & 1.49 & 1.50 & 1.17 & 0.78 & 0.87 & 1.46 & 0.71 & 0.79 & 0.91 & 1.30 & 0.46 & 0.58 \\
\hline RS & 1.91 & 2.10 & 1.75 & 1.90 & 1.45 & 0.87 & 0.92 & 1.27 & 0.71 & 1.06 & 1.29 & 1.26 & 0.42 & 0.67 \\
\hline TEL & 2.21 & 2.92 & 2.54 & 2.07 & 1.21 & 1.19 & 1.28 & 1.45 & 1.03 & 0.99 & 0.85 & 0.70 & 0.27 & 0.70 \\
\hline PROG & 1.91 & 2.10 & 1.75 & 1.90 & 1.45 & 0.87 & 0.92 & 1.27 & 0.71 & 1.06 & 1.29 & 1.26 & 0.42 & 0.67 \\
\hline ACC & 2.21 & 2.92 & 2.54 & 2.07 & 1.21 & 1.19 & 1.28 & 1.45 & 1.03 & 0.99 & 0.85 & 0.70 & 0.27 & 0.70 \\
\hline FS & 2.03 & 2.08 & 1.70 & 1.79 & 1.24 & 1.03 & 1.11 & 1.45 & 1.27 & 0.93 & 0.95 & 1.15 & 0.37 & 0.71 \\
\hline BUD & 2.27 & 2.44 & 2.02 & 2.01 & 1.64 & 1.03 & 1.10 & 1.42 & 0.91 & 0.91 & 1.57 & 1.33 & 0.42 & 0.66 \\
\hline ENG & 1.63 & 1.65 & 1.69 & 1.72 & 1.24 & 0.84 & 0.91 & 1.33 & 0.77 & 0.81 & 1.03 & 0.98 & 0.38 & 0.62 \\
\hline HCL & 2.80 & 1.20 & 3.33 & 0.48 & 0.14 & 0.92 & 1.32 & 1.62 & 0.38 & 0.73 & 0.85 & 1.10 & 0.14 & 0.42 \\
\hline PNG & 2.43 & 30.17 & -1.87 & 43.10 & -2.48 & 1.41 & 1.38 & 1.72 & 0.47 & 0.09 & 0.63 & 0.06 & 0.26 & 0.90 \\
\hline
\end{tabular}

Source: own elaboration

*PKD - Classification of Business Activities in Poland

Table 10

The coefficient of variation in 2014 calculated based on the financial data of the Accounting Act

\begin{tabular}{|l|c|c|c|c|c|c|c|c|c|c|c|c|c|c|}
\hline $\begin{array}{l}\text { Sector } \\
\text { PKD }\end{array}$ & ROA & ROE & ROSN & ROSB & ERS & CL & QL & CF & SRPP & PPP & IT & ACR & DSF & DR \\
\hline F & 1.41 & 1.54 & 1.50 & 1.59 & 1.06 & 0.74 & 0.86 & 0.87 & 0.70 & 0.70 & 1.05 & 0.67 & 0.34 & 0.54 \\
\hline B & 1.71 & 1.89 & 1.81 & 1.66 & 1.01 & 0.71 & 0.90 & 1.45 & 0.63 & 0.75 & 0.77 & 0.63 & 0.32 & 0.56 \\
\hline T & 1.19 & 1.43 & 1.52 & 1.38 & 0.99 & 0.88 & 1.10 & 1.40 & 0.62 & 0.89 & 0.83 & 0.99 & 0.37 & 0.64 \\
\hline Ch & 1.21 & 1.37 & 1.26 & 1.27 & 0.93 & 0.81 & 0.90 & 1.53 & 0.50 & 0.69 & 0.68 & 0.78 & 0.35 & 0.60 \\
\hline Ph & 1.81 & 2.07 & 1.98 & 1.70 & 1.05 & 0.87 & 1.02 & 1.43 & 0.63 & 0.80 & 0.55 & 0.83 & 0.34 & 0.67 \\
\hline C & 1.60 & 1.63 & 1.53 & 1.51 & 1.16 & 0.94 & 1.05 & 1.40 & 0.64 & 0.81 & 0.89 & 1.23 & 0.37 & 0.68 \\
\hline E & 1.34 & 1.40 & 1.42 & 1.41 & 0.95 & 0.73 & 0.83 & 1.31 & 0.58 & 0.76 & 0.67 & 0.90 & 0.34 & 0.57 \\
\hline VEH & 1.19 & 1.32 & 1.38 & 1.53 & 0.86 & 0.73 & 0.81 & 1.51 & 0.60 & 0.67 & 0.74 & 0.67 & 0.32 & 0.53 \\
\hline WS & 1.34 & 1.57 & 1.53 & 1.50 & 1.19 & 0.78 & 0.86 & 1.44 & 0.71 & 0.78 & 0.90 & 1.27 & 0.47 & 0.57 \\
\hline RS & 1.65 & 1.86 & 1.74 & 2.26 & 1.31 & 0.74 & 0.97 & 1.36 & 1.19 & 0.73 & 0.85 & 1.08 & 0.42 & 0.55 \\
\hline TEL & 1.73 & 2.18 & 2.01 & 1.92 & 1.36 & 0.98 & 1.08 & 1.51 & 0.86 & 0.75 & 1.07 & 1.05 & 0.43 & 0.61 \\
\hline PRO & & & & & & & & & & & & & & \\
G & 1.98 & 2.04 & 1.93 & 1.89 & 1.43 & 0.89 & 0.92 & 1.33 & 0.70 & 1.03 & 1.28 & 1.27 & 0.41 & 0.66 \\
\hline ACC & 2.13 & 4.11 & 3.51 & 2.14 & 1.26 & 1.18 & 1.24 & 1.49 & 0.98 & 1.05 & 0.97 & 0.65 & 0.22 & 0.69 \\
\hline FS & 1.81 & 2.29 & 1.75 & 1.83 & 1.16 & 0.93 & 0.97 & 1.27 & 1.24 & 0.96 & 0.91 & 1.08 & 0.36 & 0.64 \\
\hline BUD & 2.36 & 2.58 & 2.09 & 1.84 & 1.67 & 1.01 & 1.11 & 1.52 & 0.93 & 0.94 & 1.61 & 1.29 & 0.42 & 0.66 \\
\hline ENG & 1.72 & 1.88 & 1.76 & 1.95 & 1.25 & 0.76 & 0.84 & 1.37 & 0.77 & 0.79 & 1.01 & 1.01 & 0.42 & 0.57 \\
\hline HCL & 1.38 & 1.12 & 13.64 & 3.42 & 3.69 & 1.06 & 1.28 & 1.29 & 0.41 & 0.83 & 1.44 & 0.69 & 0.42 & 0.41 \\
\hline PNG & -1.21 & -1.29 & -18.8 & -1.24 & -2.04 & 1.13 & 1.16 & 1.24 & 0.53 & 0.99 & 0.97 & 1.18 & 0.48 & 0.90 \\
\hline
\end{tabular}


Source: own elaboration

*PKD - Classification of Business Activities in Poland

Table 11

The coefficient of variation in 2013 calculated based on the financial data of the Accounting Act

\begin{tabular}{|l|l|l|l|l|l|l|l|l|l|l|l|l|l|l|}
\hline $\begin{array}{l}\text { Sector } \\
\text { PKD }\end{array}$ & ROA & ROE & ROSN & ROSB & ERS & CL & QL & CF & SRPP & PPP & IT & ACR & DSF & DR \\
\hline F & 1.35 & 1.53 & 1.62 & 1.61 & 1.03 & 0.68 & 0.78 & 1.38 & 0.71 & 0.67 & 1.03 & 0.62 & 0.34 & 0.51 \\
\hline B & 1.47 & 1.88 & 1.80 & 1.66 & 1.08 & 0.72 & 0.83 & 1.63 & 0.47 & 0.73 & 0.84 & 0.62 & 0.36 & 0.58 \\
\hline T & 1.54 & 1.53 & 1.58 & 1.49 & 1.10 & 0.85 & 1.02 & 1.50 & 0.55 & 0.79 & 0.83 & 1.01 & 0.33 & 0.62 \\
\hline Ch & 1.30 & 1.55 & 1.52 & 1.30 & 1.06 & 0.78 & 0.85 & 1.51 & 0.48 & 0.66 & 0.70 & 0.77 & 0.32 & 0.56 \\
\hline Ph & 1.28 & 1.31 & 1.27 & 1.02 & 0.90 & 0.84 & 1.01 & 1.21 & 0.61 & 0.83 & 0.52 & 0.93 & 0.29 & 0.66 \\
\hline C & 1.60 & 1.72 & 1.60 & 1.60 & 1.36 & 0.97 & 1.07 & 1.46 & 0.67 & 0.82 & 0.81 & 1.15 & 0.35 & 0.67 \\
\hline E & 1.39 & 1.50 & 1.50 & 1.50 & 1.05 & 0.73 & 0.77 & 1.29 & 0.56 & 0.74 & 0.72 & 0.83 & 0.36 & 0.56 \\
\hline VEH & 1.16 & 1.42 & 1.40 & 1.35 & 0.10 & 0.77 & 0.78 & 1.39 & 0.60 & 0.68 & 0.69 & 0.65 & 0.36 & 0.56 \\
\hline WS & 1.42 & 1.60 & 1.58 & 1.56 & 1.22 & 0.75 & 0.84 & 1.47 & 0.71 & 0.79 & 0.89 & 1.26 & 0.47 & 0.55 \\
\hline RS & 1.72 & 1.89 & 1.80 & 2.33 & 1.31 & 0.73 & 0.93 & 1.33 & 1.01 & 0.74 & 0.89 & 1.06 & 0.44 & 0.55 \\
\hline TEL & 1.55 & 1.88 & 1.87 & 2.18 & 1.18 & 0.86 & 0.93 & 1.42 & 0.87 & 0.82 & 1.12 & 1.23 & 0.44 & 0.59 \\
\hline $\begin{array}{l}\text { PRO } \\
\text { G }\end{array}$ & 2.07 & 2.23 & 2.07 & 2.15 & 1.61 & 0.90 & 0.93 & 1.31 & 0.70 & 0.97 & 1.27 & 1.29 & 0.40 & 0.67 \\
\hline ACC & 4.08 & $\begin{array}{l}252.5 \\
0\end{array}$ & 12.18 & 3.70 & 1.48 & 1.11 & 1.23 & 1.44 & 1.00 & 0.96 & 0.97 & 0.66 & 0.26 & 0.65 \\
\hline FS & 2.34 & 2.22 & 2.48 & 2.25 & 1.34 & 1.01 & 1.07 & 1.29 & 1.22 & 0.87 & 0.88 & 1.05 & 0.38 & 0.67 \\
\hline BUD & 2.48 & 2.75 & 2.36 & 2.23 & 1.83 & 1.00 & 1.07 & 1.48 & 0.92 & 0.92 & 1.59 & 1.24 & 0.43 & 0.62 \\
\hline ENG & 2.51 & 2.54 & 2.33 & 2.86 & 1.45 & 0.71 & 0.82 & 1.39 & 0.70 & 0.78 & 0.99 & 1.01 & 0.41 & 0.52 \\
\hline HCL & 12.06 & -2.19 & -1.61 & -2.25 & -2.26 & 0.67 & 0.83 & 1.71 & 0.02 & 0.37 & 0.94 & 1.22 & 0.28 & 0.39 \\
\hline PNG & -5.41 & -1.18 & -1.34 & -1.70 & 2.17 & 0.67 & 0.65 & 0.75 & 1.03 & 1.08 & 0.00 & 0.69 & 0.52 & 0.81 \\
\hline
\end{tabular}

Source: own study based on the financial statements of the companies

*PKD - Classification of Business Activities in Poland

Table 12

The coefficient of variation in 2013 calculated based on the financial data of the Accounting Act

\begin{tabular}{|l|r|r|r|r|r|r|r|r|r|r|r|r|r|r|}
\hline $\begin{array}{l}\text { Sector } \\
\text { PKD }\end{array}$ & ROA & ROE & ROSN & ROSB & ERS & CL & QL & CF & SRPP & PPP & IT & ACR & DSF & DR \\
\hline F & 1.45 & 1.83 & 1.78 & 1.74 & 1.16 & 0.67 & 0.80 & 1.44 & 0.69 & 0.66 & 1.00 & 0.64 & 0.35 & 0.49 \\
\hline B & 2.05 & 2.09 & 2.57 & 3.74 & 1.21 & 0.77 & 0.87 & 1.29 & 0.55 & 0.58 & 0.73 & 0.60 & 0.36 & 0.55 \\
\hline T & 1.56 & 1.73 & 1.69 & 1.66 & 1.08 & 0.79 & 0.94 & 1.39 & 0.59 & 0.88 & 0.82 & 0.98 & 0.38 & 0.57 \\
\hline Ch & 1.55 & 1.65 & 1.85 & 1.63 & 1.13 & 0.77 & 0.90 & 1.47 & 0.55 & 0.67 & 0.66 & 0.79 & 0.33 & 0.57 \\
\hline Ph & 1.52 & 1.90 & 1.28 & 1.20 & 1.00 & 0.91 & 0.95 & 1.41 & 0.65 & 0.86 & 0.49 & 0.69 & 0.30 & 0.73 \\
\hline C & 1.63 & 1.98 & 1.97 & 1.93 & 1.25 & 0.91 & 1.02 & 1.40 & 0.65 & 0.80 & 0.80 & 1.02 & 0.34 & 0.65 \\
\hline E & 1.51 & 1.88 & 1.85 & 1.68 & 1.15 & 0.81 & 0.80 & 1.36 & 0.54 & 0.73 & 0.68 & 0.82 & 0.34 & 0.58 \\
\hline VEH & 1.60 & 1.94 & 1.45 & 1.04 & 4.46 & 1.15 & 3.09 & 0.01 & 0.66 & 0.74 & 21.15 & 1.65 & 0.37 & 0.54 \\
\hline WS & 1.41 & 1.62 & 1.59 & 1.63 & 1.22 & 0.73 & 0.83 & 1.47 & 0.70 & 0.97 & 0.11 & 0.06 & 47.00 & 0.54 \\
\hline RS & 1.81 & 2.17 & 1.99 & 3.84 & 1.44 & 0.71 & 0.92 & 1.31 & 1.18 & 0.71 & 0.84 & 1.01 & 0.44 & 0.52 \\
\hline TEL & 3.10 & 2.60 & 2.76 & 2.41 & 1.49 & 0.78 & 0.88 & 1.35 & 0.80 & 0.77 & 1.20 & 1.02 & 0.40 & 0.57 \\
\hline PRO & & & & & & & & & & & & & & \\
G & 1.93 & 1.98 & 1.85 & 1.91 & 1.41 & 0.88 & 0.94 & 1.30 & 0.63 & 0.96 & 1.23 & 1.24 & 0.41 & 0.65 \\
\hline ACC & 3.20 & 6.50 & 9.92 & 4.71 & 1.38 & 1.09 & 1.20 & 1.45 & 1.02 & 0.93 & 0.96 & 0.68 & 0.23 & 0.66 \\
\hline FS & 2.77 & 3.34 & 3.73 & 2.69 & 1.41 & 1.04 & 1.07 & 1.40 & 1.19 & 0.92 & 0.76 & 1.16 & 0.36 & 0.66 \\
\hline BUD & 2.35 & 2.60 & 2.65 & 2.69 & 1.95 & 0.95 & 1.07 & 1.49 & 0.91 & 0.87 & 1.64 & 1.23 & 0.44 & 0.59 \\
\hline ENG & 2.62 & 0.76 & 3.50 & 3.24 & 0.25 & 0.65 & 0.59 & 1.32 & 0.67 & 0.73 & 0.97 & 0.88 & 0.40 & 0.51 \\
\hline HCL & & & 131.2 & & & & & & & & & & & \\
& 1.87 & 2.48 & 0 & 8.19 & 5.09 & 1.03 & 1.21 & 1.76 & 0.08 & 0.47 & 1.35 & 5.90 & 1.91 & 0.36 \\
\hline PNG & 4.47 & 8.52 & 6.16 & 7.83 & 1.75 & 0.81 & 0.95 & 1.39 & 0.64 & 0.87 & 0.87 & 0.67 & 0.29 & 0.62 \\
\hline
\end{tabular}

Source: own elaboration

*PKD - Classification of Business Activities in Poland

Table 13

The coefficient of variation in 2011 calculated based on the financial data of the Accounting Act 


\begin{tabular}{|l|r|r|r|r|r|r|r|r|r|r|r|r|r|r|}
\hline \multicolumn{1}{|c|}{ Sector PKD* } & ROA & ROE & $\begin{array}{r}\text { ROS } \\
\mathbf{N}\end{array}$ & $\begin{array}{r}\text { ROS } \\
\mathbf{B}\end{array}$ & ERS & CL & QL & CF & SRPP & PPP & IT & ACR & DSF & DR \\
\hline F & 1.31 & 1.61 & 1.75 & 1.67 & 1.07 & 0.64 & 0.75 & 1.38 & 0.70 & 0.69 & 0.99 & 0.61 & 0.35 & 0.47 \\
\hline B & 2.01 & 3.17 & 2.85 & 3.09 & 1.46 & 0.64 & 0.71 & 1.43 & 0.57 & 0.76 & 0.66 & 0.67 & 0.36 & 0.49 \\
\hline T & 1.26 & 1.69 & 1.83 & 1.95 & 1.10 & 4.24 & 1.22 & 3.38 & 0.08 & 0.78 & 0.48 & 26.50 & 2.80 & 0.00 \\
\hline Ph & 1.14 & 1.63 & 1.47 & 1.20 & 0.93 & 0.76 & 0.87 & 1.36 & 0.53 & 0.61 & 0.68 & 0.78 & 0.34 & 0.57 \\
\hline C & 1.95 & 2.25 & 1.51 & 1.19 & 0.94 & 0.78 & 0.87 & 1.38 & 0.51 & 0.83 & 0.51 & 0.78 & 0.28 & 0.72 \\
\hline E & 1.39 & 1.68 & 1.46 & 1.42 & 1.08 & 0.85 & 0.93 & 1.37 & 0.64 & 0.78 & 0.77 & 0.99 & 0.36 & 0.61 \\
\hline VEH & 1.20 & 1.39 & 1.35 & 1.31 & 0.93 & 0.67 & 0.82 & 1.33 & 0.54 & 0.67 & 0.64 & 0.78 & 0.34 & 0.55 \\
\hline WS & 1.19 & 1.49 & 1.66 & 1.42 & 1.01 & 0.65 & 0.82 & 1.34 & 0.51 & 0.63 & 0.67 & 0.73 & 0.38 & 0.51 \\
\hline RS & 1.24 & 1.52 & 1.56 & 1.31 & 0.39 & 0.62 & 0.76 & 1.42 & 0.69 & 0.76 & 0.85 & 1.23 & 0.48 & 0.51 \\
\hline TEL & 1.74 & 2.08 & 1.94 & 3.14 & 1.37 & 0.66 & 0.89 & 1.24 & 1.18 & 0.70 & 0.83 & 1.01 & 0.45 & 0.49 \\
\hline PROG & 2.81 & 4.67 & 2.22 & 3.07 & 1.62 & 0.88 & 0.93 & 1.29 & 0.82 & 0.89 & 1.19 & 1.09 & 0.40 & 0.61 \\
\hline ACC & 1.80 & 1.73 & 1.71 & 1.67 & 1.36 & 0.91 & 0.94 & 1.29 & 0.69 & 1.00 & 1.16 & 1.27 & 0.38 & 0.64 \\
\hline FS & 2.30 & 4.42 & 6.89 & 3.81 & 1.32 & 1.10 & 1.18 & 1.42 & 0.94 & 0.99 & 0.93 & 0.61 & 0.20 & 0.68 \\
\hline BUD & 2.04 & 2.23 & 2.99 & 3.40 & 1.37 & 0.96 & 0.95 & 1.29 & 1.17 & 0.82 & 0.81 & 0.94 & 0.39 & 0.60 \\
\hline ENG & 2.03 & 2.48 & 2.08 & 2.04 & 1.62 & 0.80 & 0.94 & 1.42 & 0.86 & 0.84 & 1.64 & 1.25 & 0.47 & 0.55 \\
\hline HCL & 2.03 & 2.15 & 2.16 & 2.35 & 1.28 & 0.64 & 0.73 & 1.32 & 0.66 & 0.70 & 0.95 & 0.84 & 0.41 & 0.48 \\
\hline PNG & 0.67 & 1.27 & 0.79 & 0.76 & 0.60 & 1.34 & 1.47 & 1.46 & 0.45 & 0.50 & 0.43 & 0.90 & 0.16 & 0.55 \\
\hline SOurce & -1.20 & 0.98 & -0.96 & 0.97 & -1.10 & 1.26 & 0.20 & 1.24 & 0.05 & 0.78 & 0.00 & 0.21 & 0.26 & 0.62 \\
\hline
\end{tabular}

Source: own elaboration

*PKD - Classification of Business Activities in Poland

Table 14

The coefficient of variation in 2010 calculated based on the financial data of the Accounting Act

\begin{tabular}{|l|r|r|r|r|r|r|r|r|r|r|r|r|r|r|}
\hline Sector PKD* & ROA & ROE & ROSN & ROSB & ERS & CL & QL & CF & $\begin{array}{c}\text { SRP } \\
\text { P }\end{array}$ & PPP & IT & ACR & DSF & DR \\
\hline F & 1.26 & 1.40 & 1.52 & 1.60 & 0.99 & 0.68 & 0.76 & 1.39 & 0.71 & 0.68 & 0.94 & 0.61 & 0.31 & 0.48 \\
\hline B & 1.46 & 1.34 & 1.86 & 2.20 & 1.18 & 0.68 & 0.70 & 1.17 & 0.58 & 0.67 & 0.66 & 0.79 & 0.33 & 0.54 \\
\hline T & 1.56 & 1.86 & 1.92 & 2.27 & 1.20 & 0.70 & 0.80 & 1.36 & 0.68 & 0.73 & 0.80 & 0.92 & 0.34 & 0.53 \\
\hline Ch & 1.29 & 1.41 & 1.46 & 1.40 & 1.00 & 0.73 & 0.83 & 1.45 & 0.51 & 0.63 & 0.64 & 0.74 & 0.32 & 0.57 \\
\hline Ph & 1.66 & 1.93 & 2.46 & 1.60 & 1.65 & 0.80 & 0.86 & 1.32 & 0.52 & 0.69 & 0.53 & 0.81 & 0.32 & 0.75 \\
\hline C & 1.67 & 1.90 & 1.99 & 2.29 & 1.41 & 0.80 & 0.86 & 1.41 & 0.59 & 0.72 & 0.79 & 0.91 & 0.35 & 0.57 \\
\hline E & 1.21 & 1.36 & 1.36 & 1.47 & 1.01 & 0.70 & 0.76 & 0.01 & 0.69 & 0.59 & 14.06 & 3.05 & 0.00 & 0.54 \\
\hline VEH & 1.27 & 1.47 & 1.54 & 1.70 & 1.11 & 0.68 & 0.76 & 1.35 & 0.50 & 0.66 & 0.73 & 0.74 & 0.35 & 0.51 \\
\hline WS & 1.24 & 1.41 & 1.46 & 1.47 & 1.12 & 0.69 & 0.77 & 1.42 & 0.69 & 0.76 & 0.87 & 1.19 & 0.47 & 0.51 \\
\hline RS & 1.51 & 1.75 & 1.65 & 2.86 & 1.22 & 0.65 & 0.89 & 1.27 & 1.21 & 0.71 & 0.85 & 0.96 & 0.42 & 0.49 \\
\hline TEL & 2.12 & 2.66 & 2.69 & 4.23 & 1.56 & 0.88 & 0.90 & 1.40 & 0.75 & 0.76 & 1.21 & 0.96 & 0.37 & 0.62 \\
\hline PROG & 1.82 & 1.82 & 1.59 & 1.77 & 1.27 & 0.92 & 0.93 & 1.27 & 0.68 & 0.94 & 1.18 & 1.23 & 0.38 & 0.66 \\
\hline ACC & 2.19 & 3.01 & 8.70 & 4.05 & 1.21 & 1.14 & 1.23 & 1.47 & 0.89 & 0.86 & 0.84 & 0.66 & 0.20 & 0.70 \\
\hline FS & 2.17 & 2.03 & 2.47 & 2.20 & 1.35 & 0.92 & 0.92 & 1.23 & 1.10 & 0.80 & 0.73 & 0.88 & 0.42 & 0.58 \\
\hline BUD & 2.05 & 2.19 & 1.74 & 1.94 & 1.48 & 0.81 & 0.97 & 1.39 & 0.86 & 0.83 & 1.58 & 1.18 & 0.44 & 0.54 \\
\hline ENG & 1.54 & 1.71 & 1.74 & 1.60 & 1.06 & 0.66 & 0.75 & 1.23 & 0.65 & 0.68 & 0.93 & 0.78 & 0.36 & 0.48 \\
\hline HCL & 1.04 & 1.00 & 1.14 & 0.85 & 0.79 & 0.86 & 0.96 & 1.08 & 0.28 & 0.61 & 0.47 & 0.87 & 0.14 & 0.55 \\
\hline PNG & 1.36 & 1.41 & 1.67 & 1.33 & 0.97 & 0.88 & 1.02 & 1.47 & 0.56 & 0.89 & 0.87 & 0.57 & 0.26 & 0.58 \\
\hline
\end{tabular}

Source: own elaboration

*PKD - Classification of Business Activities in Poland

Table 15

The coefficient of variation in 2009 calculated based on the financial data of the Accounting Act

\begin{tabular}{|l|c|c|c|r|c|c|c|c|c|c|c|c|c|c|}
\hline Sector PKD* & ROA & ROE & $\begin{array}{r}\text { ROS } \\
\mathbf{N}\end{array}$ & $\begin{array}{r}\text { ROS } \\
\text { B }\end{array}$ & ERS & CL & QL & CF & SRPP & PPP & IT & ACR & DSF & DR \\
\hline F & 1.22 & 1.51 & 1.49 & 1.52 & 1.01 & 0.68 & 0.81 & 1.46 & 0.74 & 0.71 & 0.94 & 0.65 & 0.33 & 0.50 \\
\hline B & 1.43 & 1.79 & 1.83 & 1.76 & 0.98 & 0.66 & 0.79 & 1.29 & 0.58 & 0.74 & 0.80 & 0.64 & 0.34 & 0.50 \\
\hline T & 2.07 & 2.96 & 4.24 & 3.31 & 1.46 & 0.74 & 0.83 & 1.35 & 0.57 & 0.73 & 0.90 & 0.86 & 0.34 & 0.55 \\
\hline Ch & 1.40 & 1.71 & 1.69 & 1.47 & 1.09 & 0.79 & 0.86 & 1.51 & 0.52 & 0.70 & 0.64 & 0.71 & 0.31 & 0.59 \\
\hline
\end{tabular}




\begin{tabular}{|l|l|l|l|l|l|l|l|l|l|l|l|l|l|l|}
$\mathrm{Ph}$ & 1.39 & 1.46 & 1.45 & 1.17 & 1.09 & 0.67 & 0.78 & 1.17 & 0.57 & 0.64 & 0.50 & 0.69 & 0.27 & 0.69 \\
\hline C & 1.59 & 1.76 & 2.34 & 2.53 & 1.53 & 0.81 & 0.99 & 1.38 & 0.66 & 0.82 & 0.87 & 1.03 & 0.37 & 0.57 \\
\hline E & 1.46 & 1.82 & 1.84 & 1.65 & 1.19 & 0.74 & 0.79 & 1.44 & 0.51 & 0.68 & 0.64 & 0.69 & 0.29 & 2.06 \\
\hline VEH & 1.85 & 2.85 & 4.12 & 2.91 & 1.29 & 0.77 & 0.86 & 1.43 & 0.51 & 0.71 & 0.83 & 0.76 & 0.34 & 0.53 \\
\hline WS & 1.28 & 1.49 & 1.57 & 1.50 & 1.15 & 0.70 & 0.82 & 1.45 & 0.70 & 0.74 & 0.84 & 1.19 & 0.47 & 0.51 \\
\hline RS & 1.47 & 1.61 & 1.53 & 2.17 & 1.21 & 0.69 & 0.93 & 1.29 & 1.24 & 0.72 & 0.82 & 1.02 & 0.41 & 0.50 \\
\hline TEL & 2.12 & 2.41 & 2.58 & 2.10 & 1.66 & 1.08 & 1.10 & 1.41 & 0.68 & 0.84 & 1.04 & 1.29 & 0.38 & 0.66 \\
\hline PROG & 2.06 & 1.89 & 2.02 & 1.96 & 1.49 & 0.91 & 0.93 & 1.26 & 0.65 & 0.97 & 1.08 & 1.20 & 0.39 & 0.64 \\
\hline ACC & 1.99 & 2.58 & 2.34 & 2.89 & 1.14 & 1.02 & 1.03 & 1.29 & 0.89 & 0.92 & 0.86 & 0.63 & 0.19 & 0.70 \\
\hline FS & 2.90 & 2.50 & 2.08 & 2.94 & 1.79 & 0.95 & 1.03 & 1.29 & 1.20 & 0.73 & 0.70 & 0.81 & 0.44 & 0.63 \\
\hline BUD & 1.71 & 1.84 & 1.63 & 1.65 & 1.40 & 0.81 & 0.94 & 1.38 & 0.84 & 0.80 & 1.60 & 1.17 & 0.43 & 0.54 \\
\hline ENG & 1.32 & 1.56 & 1.40 & 1.45 & 1.01 & 0.61 & 0.70 & 1.14 & 0.74 & 0.70 & 0.92 & 0.73 & 0.35 & 0.48 \\
\hline HCL & 1.46 & 1.03 & 1.76 & 1.63 & 2.52 & 1.02 & 0.96 & 1.06 & 0.32 & 0.82 & 0.35 & 0.97 & 0.17 & 0.55 \\
\hline PNG & 1.26 & 1.46 & 1.39 & 1.24 & 0.87 & 0.89 & 1.06 & 1.46 & 0.50 & 0.92 & 0.90 & 0.50 & 0.26 & 0.63 \\
\hline
\end{tabular}

Source: own elaboration

*PKD - Classification of Business Activities in Poland 